\title{
Identification and Evaluation of Human Errors Leading to Incidents in a Gas Refinery using Human Factors Analysis and Classification System
}

\author{
Gholam Abbas Shirali', Mojtaba Nakhaei pour ${ }^{2}$, Fereshteh Jahani3 ${ }^{3, *}$, Mehdi Shakib ${ }^{4}$, \\ Iman Mir ${ }^{5}$ \\ ${ }^{I}$ Associate Professor, Department of Occupational Health Engineering, School of Public Health, Ahvaz Jundishapur \\ University of Medical Sciences, Ahvaz, Iran \\ ${ }^{2}$ MSc in Occupational Health Engineering, Jundishapour University of Medical Sciences, Ahvaz, Iran \\ ${ }^{3}$ MSc in Occupational Health Engineering, Jundishapour University of Medical Sciences, Ahvaz, Iran \\ ${ }^{4}$ MSc in Industrial Management, Tehran University, Tehran, Iran \\ ${ }^{5}$ MSc in Biostatistics, Jundishapour University of Medical Sciences, Ahvaz, Iran \\ * Corresponding Author: Fereshteh Jahani, Jundishapour University of Medical Sciences, Ahvaz, Iran. Email: \\ jahani.f71@gmail.com
}

Received: 06/08/2017

Accepted: 10/01/2018

How to Cite this Article:

Shirali GA, Nakhaei pour M, Jahani F, Shakib M, Mir I. Identification and Evaluation of Human Errors Leading to Incidents in a Gas Refinery using Human Factors Analysis and Classification System. $J$ Occup Hyg Eng. 2018; 4(4): 111. DOI:

\section{Abstract}

Background and Objective: Incidents are one of the most important causes of damages in an organization often occurring due to a chain of minor and trivial errors. Each error may have minor consequences, but in synergy, the system invariably heads towards serious and disastrous consequences. Therefore, we aimed to identify human errors leading to incidents in a gas refinery using human factors analysis and classification system (HFACS). Materials and Methods: A retrospective study was performed in a gas refinery. Data regarding incidents were gathered from that center. First, root causes analysis reports (RCA) of incidents occurred during the past eight years were prepared. Then, they were analyzed by using the HFACS model. Results: Most errors were associated with the first level, that is, errors caused by unsafe acts, which in the first level they were related to "violations", in the second level to "physical environment", in the third level to "inadequate supervision", and in the fourth level to "management of resources".

Conclusion: Our results showed the causes of accidents and several shortcomings in the refinery. Human errors in an organization can be reduced by utilizing administrative controls, creating an appropriate learning environment, and raising employee awareness at the same time.

Keywords: HFACS; Human Error; Gas Refinery; Root Cause Analysis 
do:

مقاله بزوهشى

\section{شناسايى و ارزيابى خطاهاى انسانى منجر به حوادث در يكى از بالايشعاههاى كاز با استفاده از روش ثجزيه و تحليل فاكتورهاى انسانى و طبقهبندى سيستم}

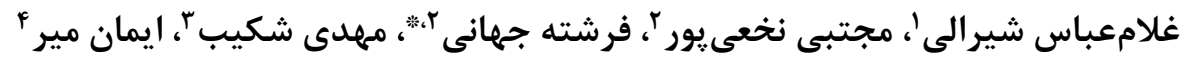

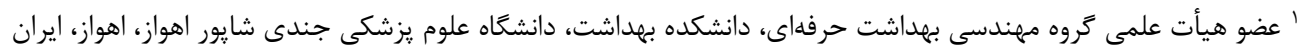

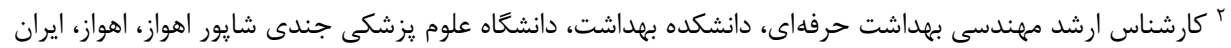

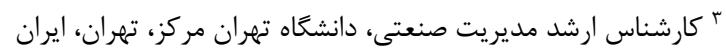

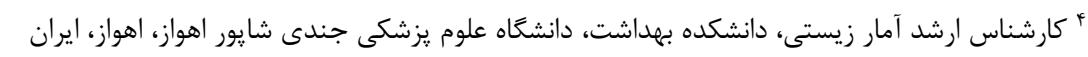
" *ويسنده مسئول: فرشته جهانى، دانشكده بهداشت، دانشكاه علوم يزشكى جندى شايور اهواز، اهواز، ايران. ايميل: jahani.f71@gmail.com

\section{جكيده}

سابقه و هدف: حوادث يكى از مهمترين علل بروز خسارت در يك سازمان مىباشند كه به واسطه سلسلهاى

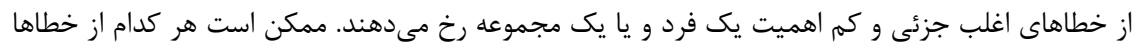

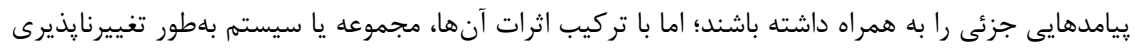

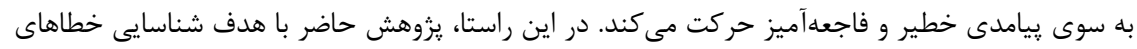

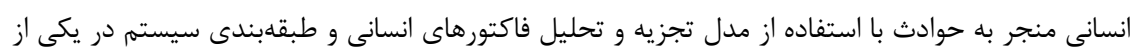

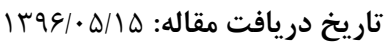

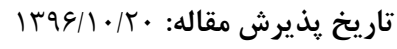
تمامى حقوق نشر براى دانشگاه علوم يزشكى همدان محفوظ است.

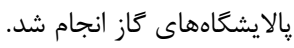

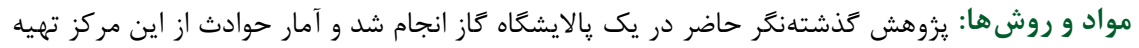

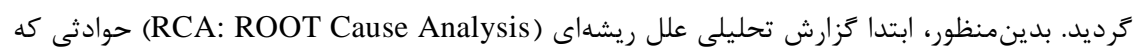

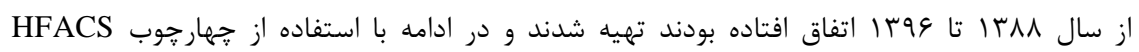
تجزيه و تحليل ترديدند. (Human Factors Analysis and Classification System)

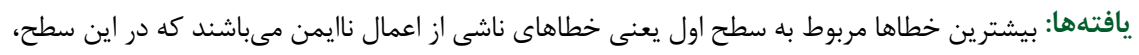

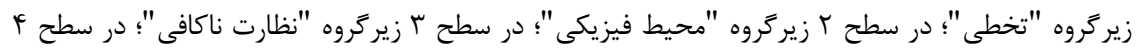

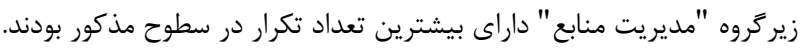

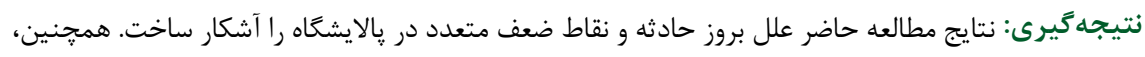

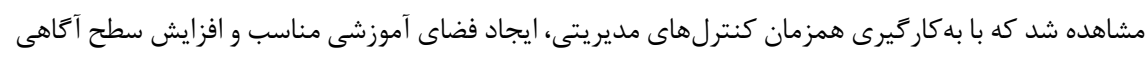

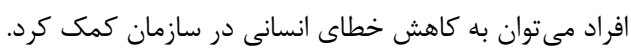

وازَّان كليدى: پِالايشَاه كَاز؛ تحليل علل ريشهاى؛ خطاى انسانى؛ HFACS

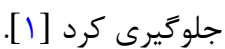

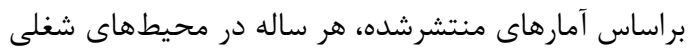

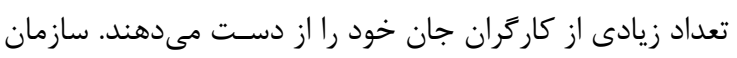

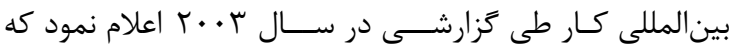

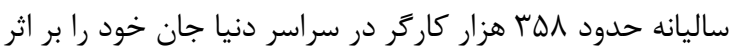

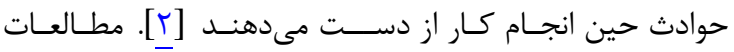

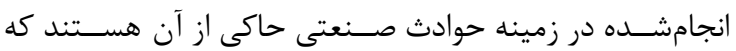

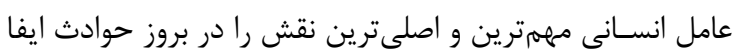

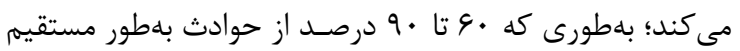

يكى از مهمترين دلايل بروز خسارت در يك سازمان حوادث

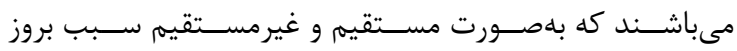

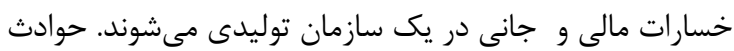

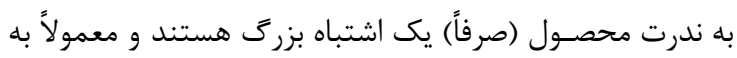

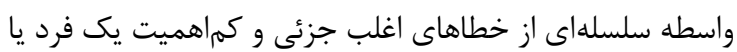

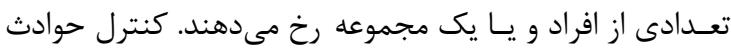

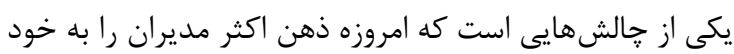

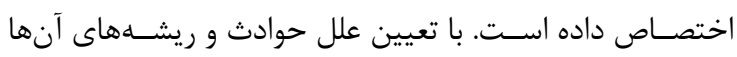

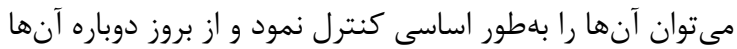


بلهوجودآورنده حادثه يِيشبينى گشـته و شـناسايى مىشوند و استراتثى بهبود را توسعه مىبخشند [11)]

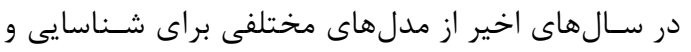

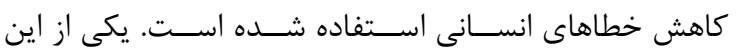

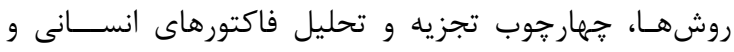

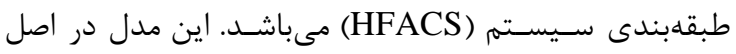

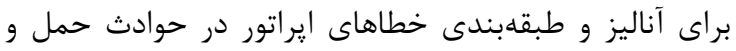

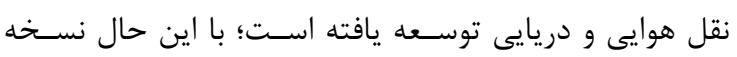

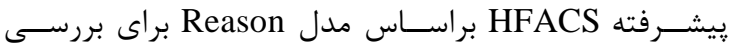

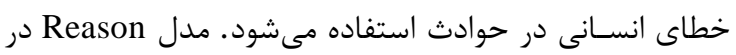
سـال •199 براى شـناسـايى خطاى انسانى در سوانح هوايى اديى

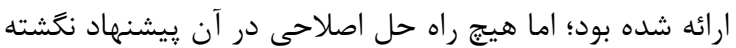

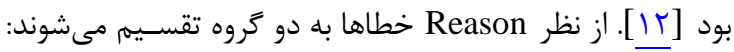
خطـاهـاى فعـال (Active Failure) كه همان خطاهاى كاربر هســتــد و خطـاهـاى ينهـان (Latent Failure) كه نقايص

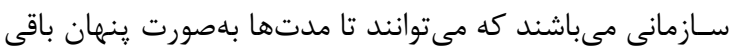

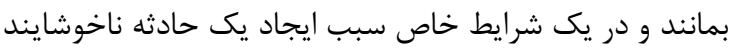

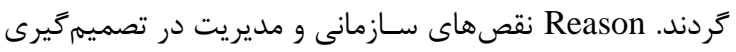
را عوامل بيمارىزاى سازمانى ميى داند (شكل (1).

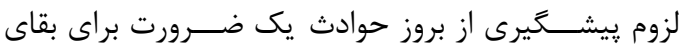

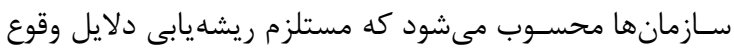

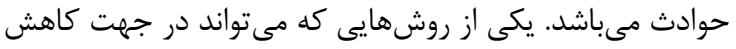

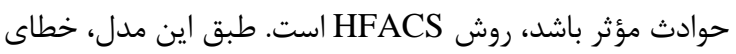

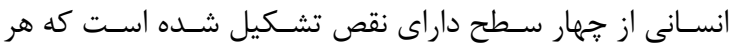

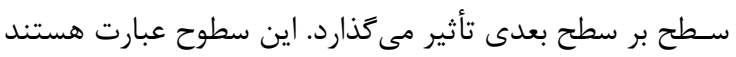

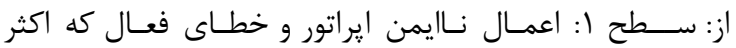
تحقيقات بر اين سـطح متمركز شـدهاند. اين سطح به دو دسته

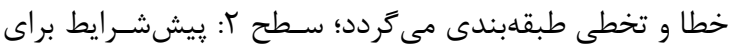

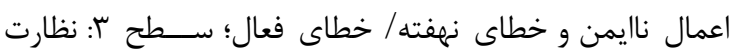

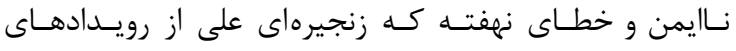

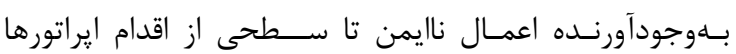

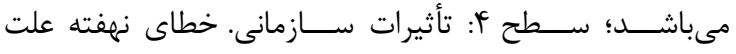

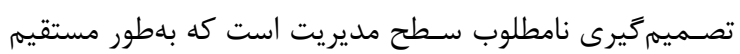

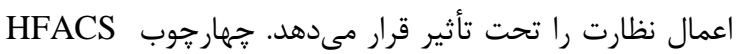
در شـكل r ارائه شـده است. شايان ذكر مى باشد كه ته
از خطاها و اشتباهات انسانى ناشى مىشوند [ب].

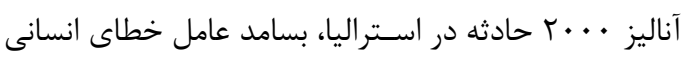

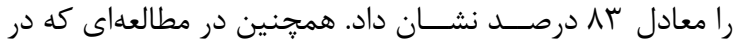
دانشــــاه فنى برلين (Technical University of Berlin)

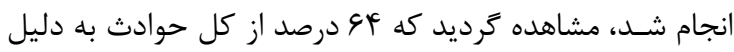

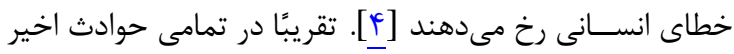

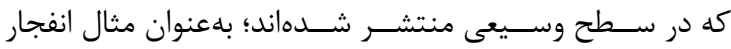

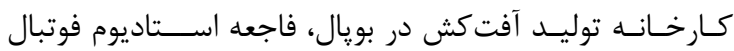

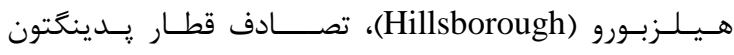
(Paddington)

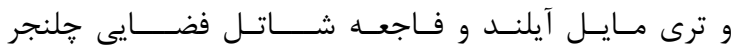
رديايى از خطاى انســانى مشــاهده (Challenger Shuttle)

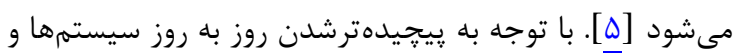

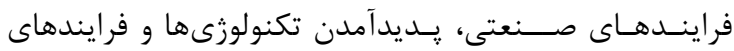
يرخطر، خصـلت خطايذيرى و غير قابل ييشبينى بودن انسان

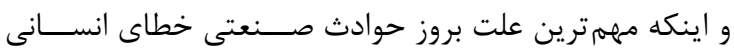

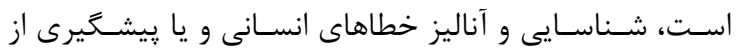

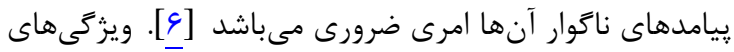

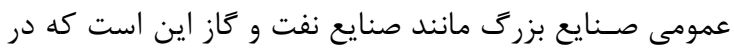
آنهـا مقـادير زيـادى از مواد خطرنـاك در يكى واحد متمركز

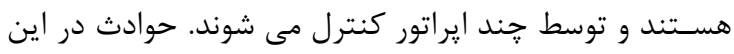

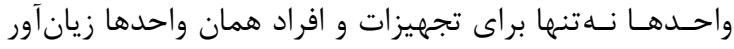

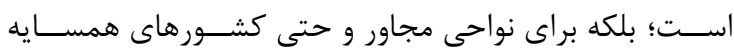

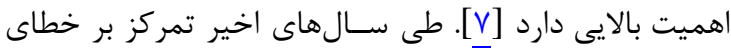

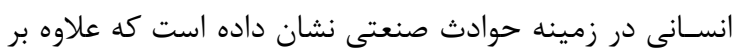

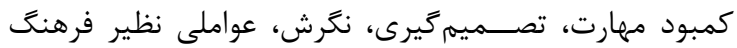

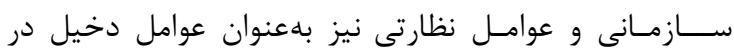

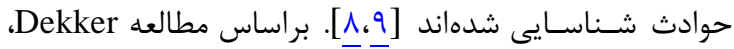

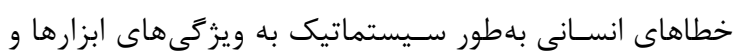

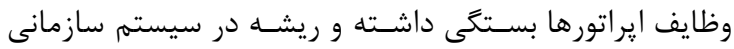

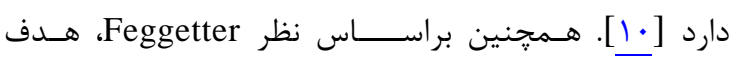

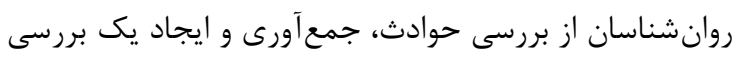
دقيق از اطلاعات مربوط به خطاى انسانى براى بهدست آدرآ آوردن

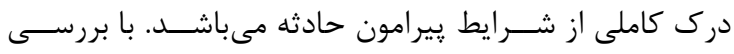

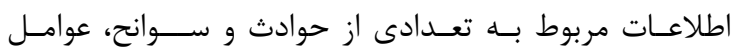

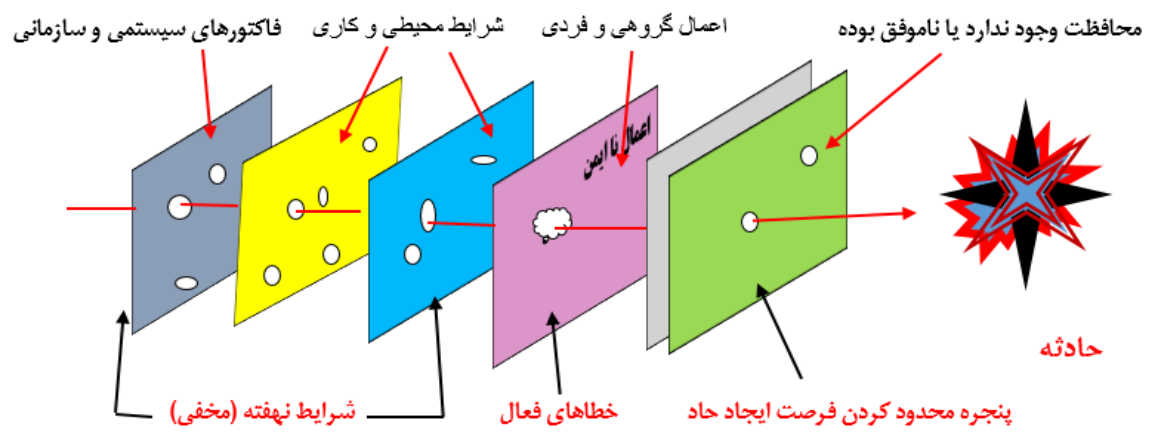

شكل ا: مدل پِنير سوئيسى Reason 


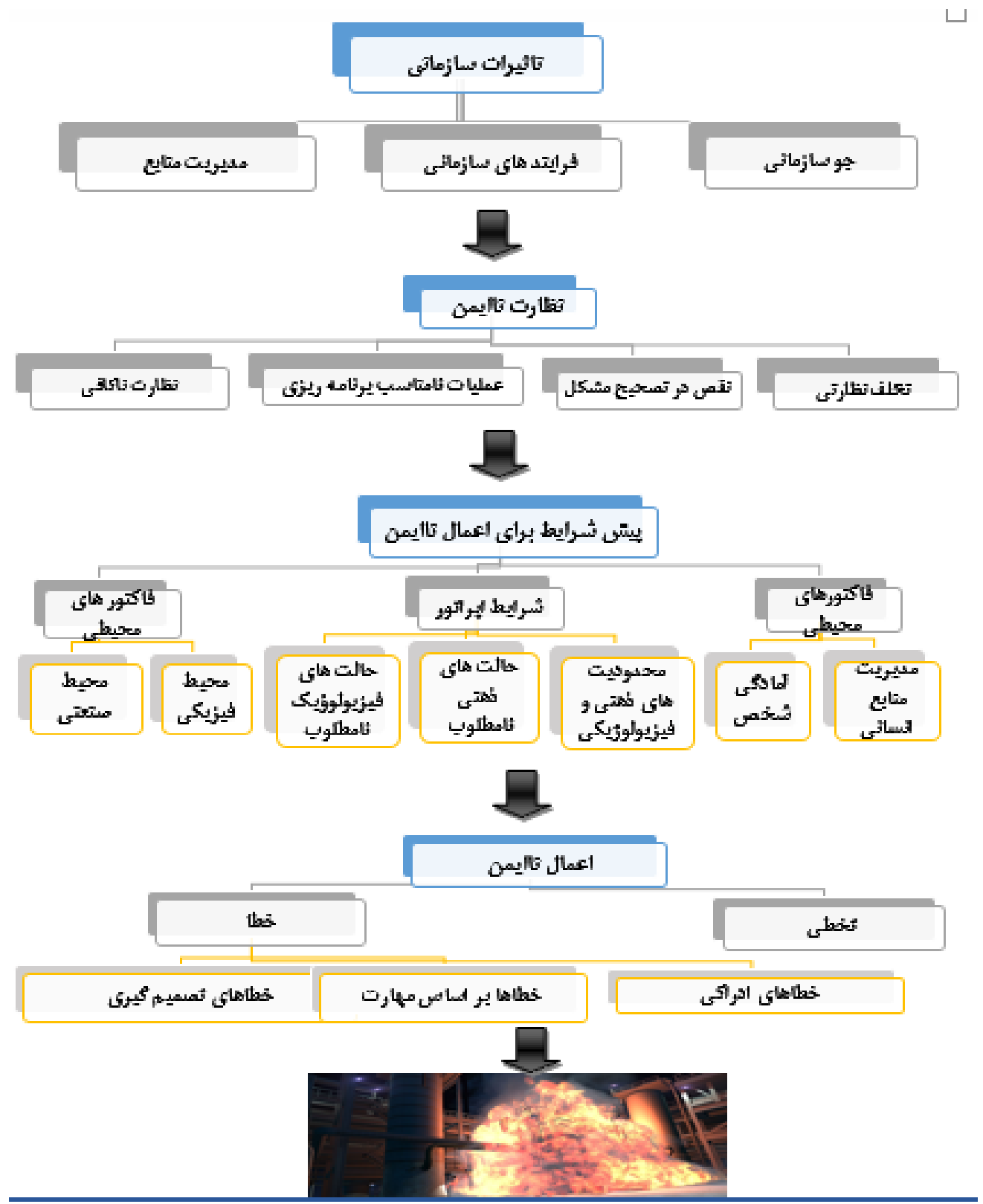

شكل r: جهار : شوب روش فاكتورهاى انسانى و طبقهبندى سيستم HFACS

حادثه مىشـوند كاهش يابد؟ شـايان توجه اسـت كه با بررسى إنى

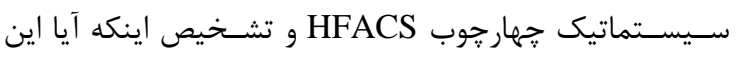

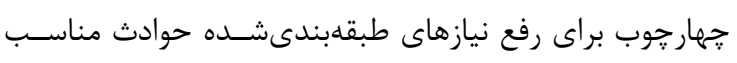

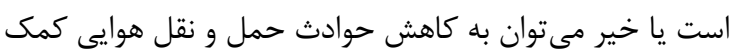

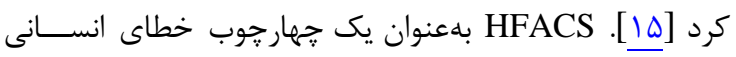

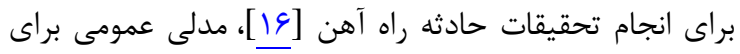

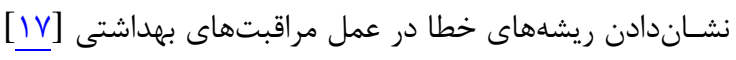

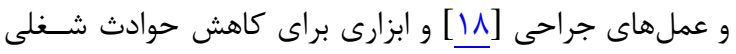

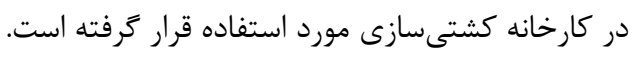
Daramola

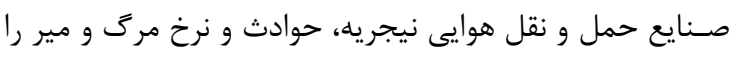

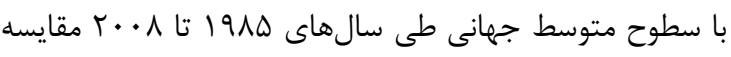

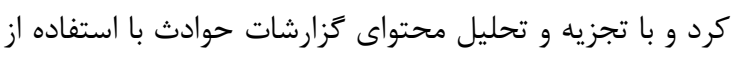
روش HFACS نشــان داد كه اغلب خطاى مهارتى، محيط مجله مهندسى بهداشت حرفهاى، دوره F، شماره F، زمستان عqجا

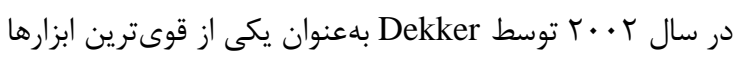

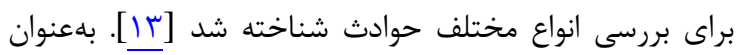

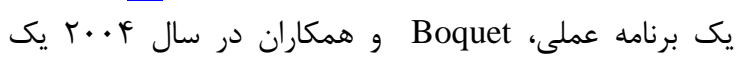

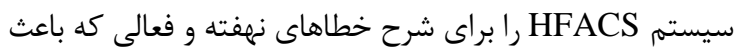

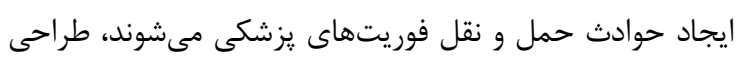
كردند [1 إجاد حوادث] Shappell و Wiegman

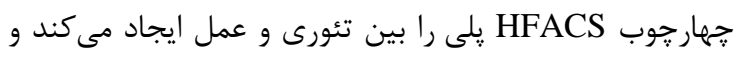

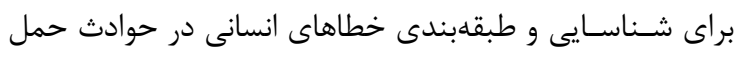

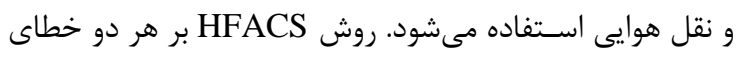

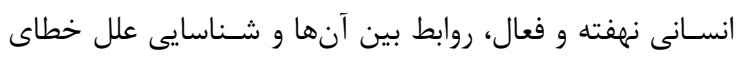

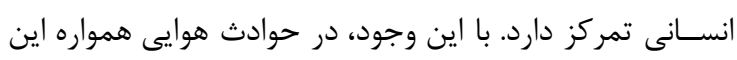

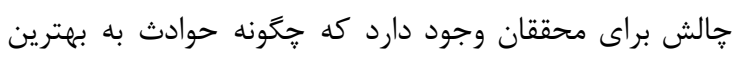

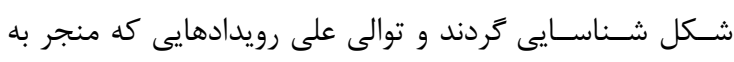




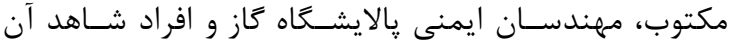

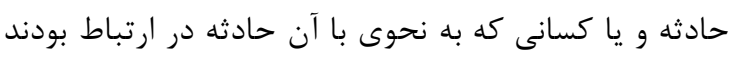

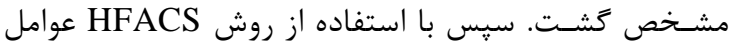

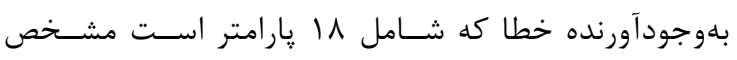

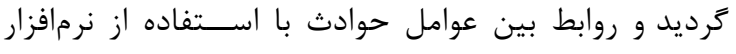
SPSS 21 بهبود ارائه گرديد.

\section{تجزيه و تحليل علل ريشهاى (RCA)}

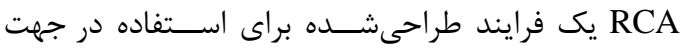

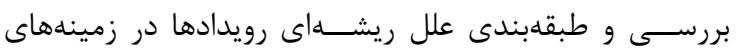

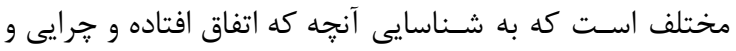

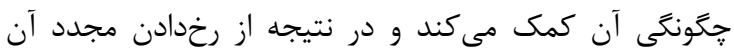

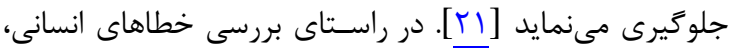

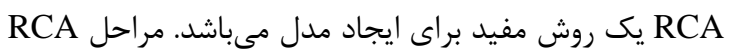

$$
\text { به شرح زير مشخص شده است: }
$$
مرحلـه ا (جمعآورى اطلاعات): بدون اطلاعات كامل و و درئ

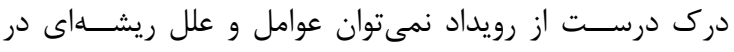

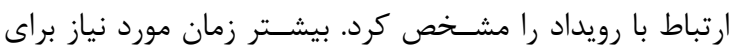

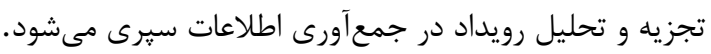

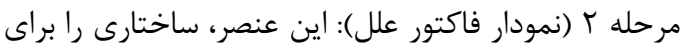

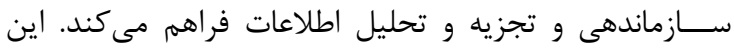

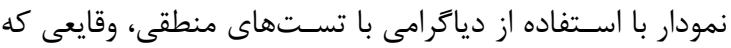
منجر به حادثه مىشوند را توصيف مىنمايد.

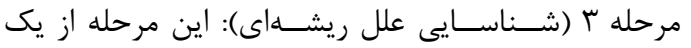

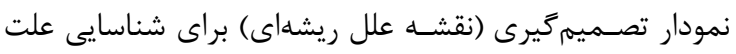
اصلى و يا دلايلى براى فاكتورهاى على استفاده مى كند.

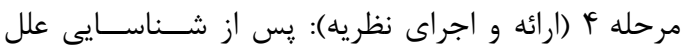

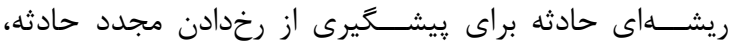
نظريهاى ارائه و اجرا مى كردد.

تجزيه و تحليل فاكتورهاى انسانى و طبقهبندى سيسته

(HFACS)

HFACS

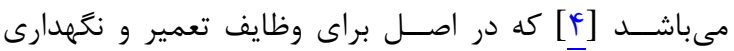

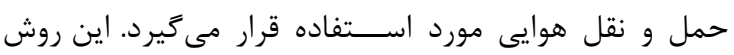

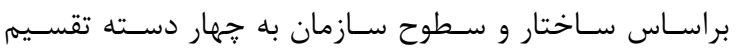

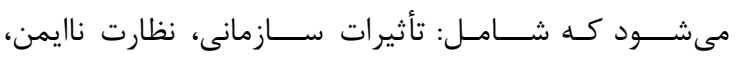

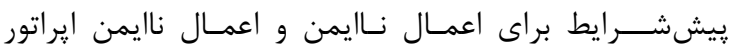
مىباشد (شكل () ). ســـ "اعمال نايمن" نماينده اكثر تحقيقات حوادث

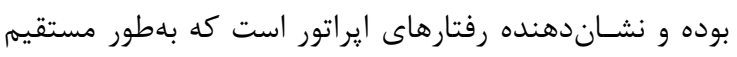
باعث ايجاد حادثه شــده و فرمى از خطاهاى فعال در حاد حادثه

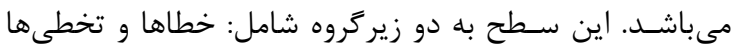

فيزيكى و نظارت ناكافى باعث ايجاد حادثه مىشـوند و روابط

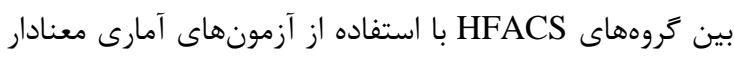

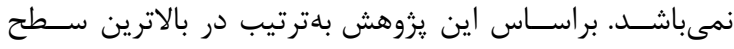
تخطى نظارتى، مديريت منابع و خطاى تصميم قوى إترين حالت الت

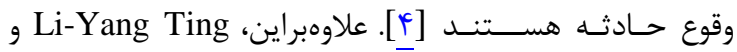

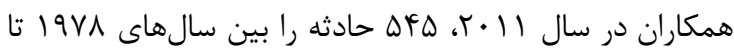

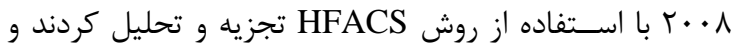
دريافتند كه سـطح اول بهطور قابل توجهى تحت تأثير سـط درح

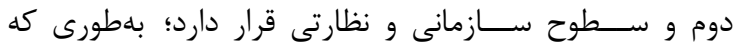

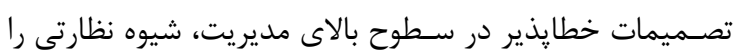

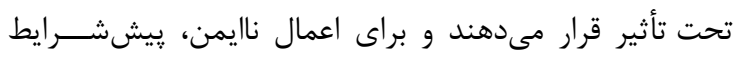

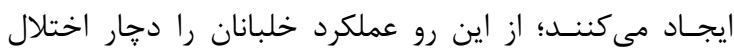

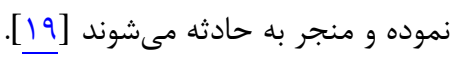

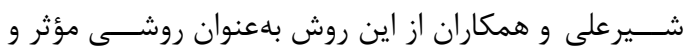
سـودمند جهت مطالعه خطاى انسـانى در صنايع نام بردهاند كه

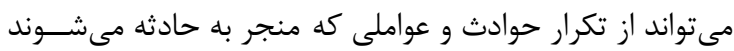

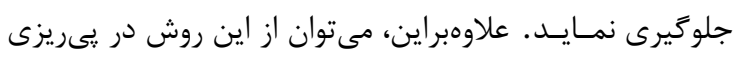

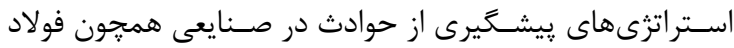

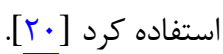
با توجه به اينكه تاكنون هيجَّونه مطالعهاى جهت آنادئ

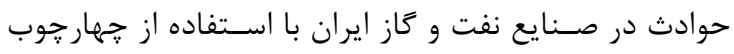

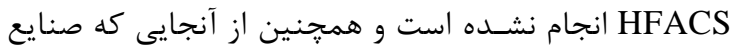

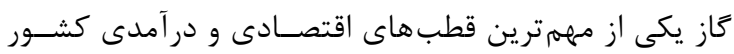

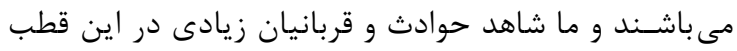

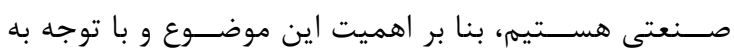

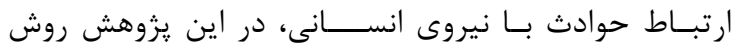

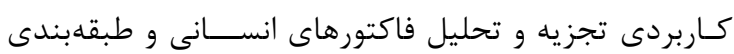

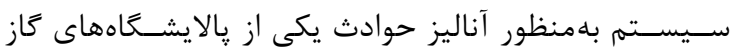

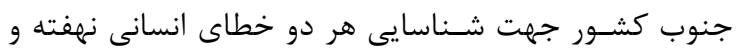

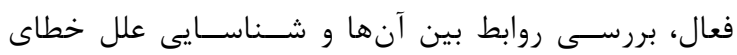

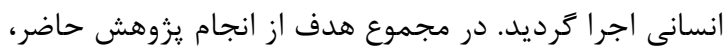

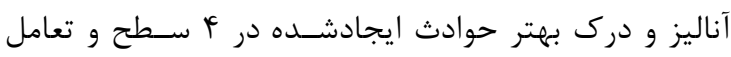

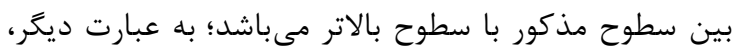

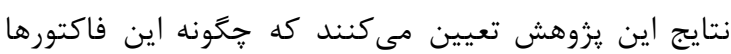

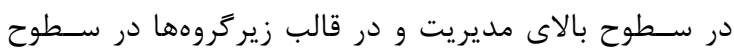
عملياتى تأثير مى كذارند.

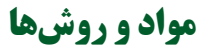

جهت انجام اين بزوهش در سـال هوبا ابتدا كروهى متشكل از ه كارشناس (مهندس ايمنى و بهداشت حرفهاى ائ)

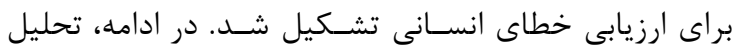

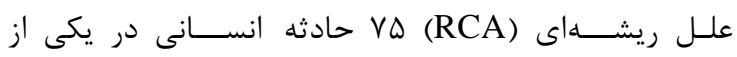

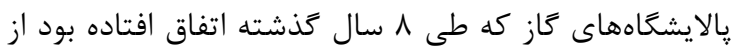

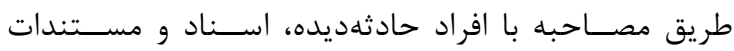


حادثه بودند و يا به نحوى با آن حادثه ارتباط داشتند انجام شد.

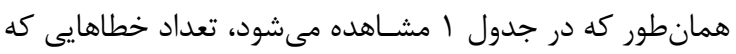

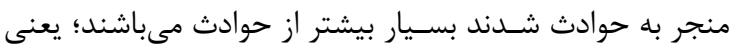

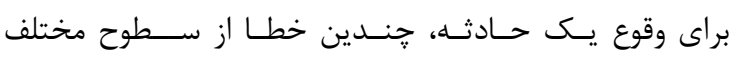

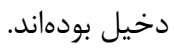

آناليز حوادث نشان داد كه 11 آ خطا مربوط به سطح اول،

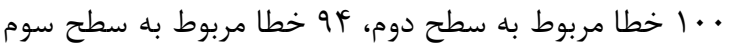

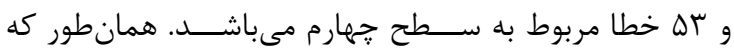

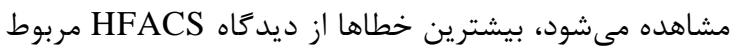
به ســطح اول يعنى خطاهاى ناشـى از اعمال نايمن إيراتورها

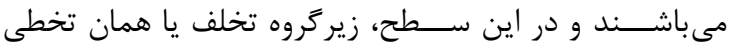

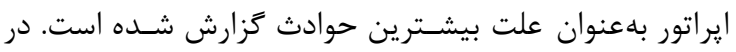

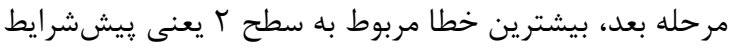

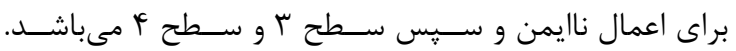

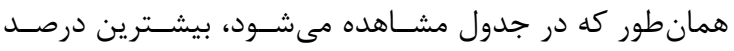

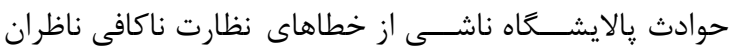

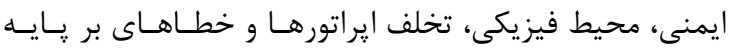

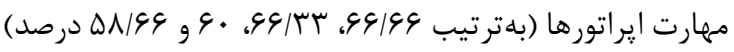

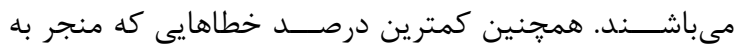

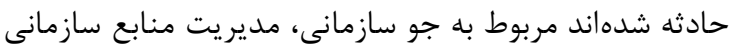

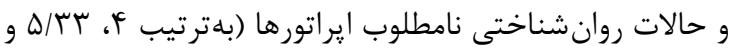

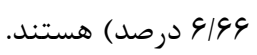

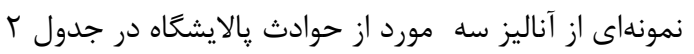

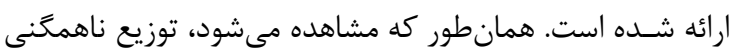

(موارد بىتوجهى عمـدى بـهـ قوانينى كـه منجر بـهـ حادثه

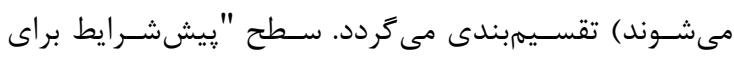
اعمال نايمن" دربرَيرنده پِيشســازهاى روانى خطاى فعال

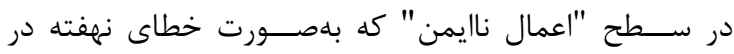

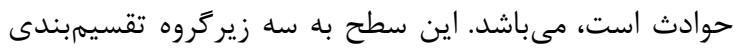

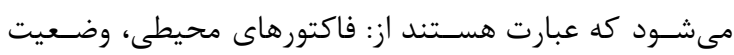

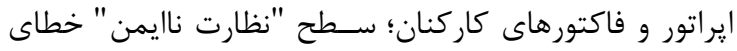

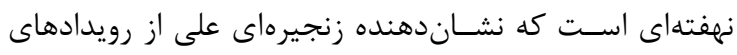

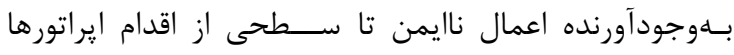

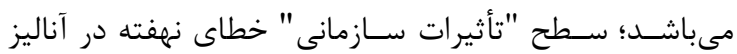

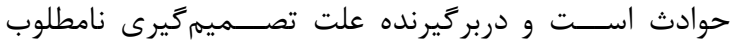
مديريت كه بهطور مسـتقيم اعمال نظارت را تحت تأثير قرار مى دهد مىباشد. جهت علامت و يا كدگذارى روش HFACS و تجزيه و

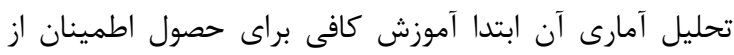

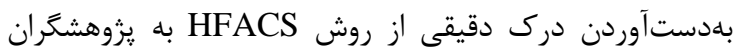

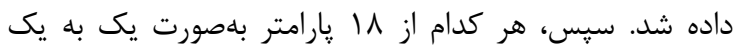
بررسى گرديدند و خطاهايى كه باعث حادثه شدند، علامت كذارى

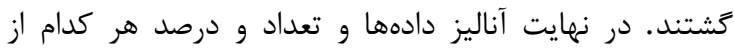

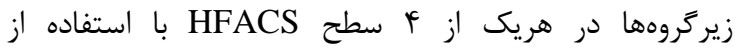
نرمافزار SPSS 21 نعيين ترديد.

بافته. آنا آناليز حوادث توسط مهندسان ايمنى و افرادى كه شاهد آن

جدول ا: تعداد و درصد حوادث پالايشگاه در زيركروه HFACS

\begin{tabular}{|c|c|c|c|}
\hline درصد & ت تعداد & 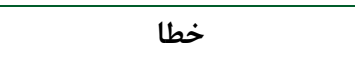 & سطوح HFACS \\
\hline$\Delta N / 99$ & fy & خطاهاى بر קايه مهارت & \multirow{4}{*}{ سطح | (اعمال نايمن ايراتورها) } \\
\hline ir & 9 & خطاهاى تصميمَيرى & \\
\hline 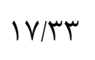 & r & خطاهاى ادراكى & \\
\hline 4. & is & تخلف & \\
\hline$\wedge$ & 4 & حالت ذهنى نامطلوب & \multirow{7}{*}{ سطح ז (ييششرايط براى اعمال نايمن) } \\
\hline 9199 & $\Delta$ & حالات روانشناختى نامطلوب & \\
\hline 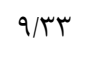 & v & محدوديتهاى ذهنى يا فيزيكى & \\
\hline 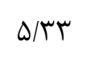 & r & مديريت منابع انسانى & \\
\hline $\mid f / 99$ & 11 & آمادگى شخص & \\
\hline 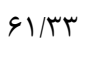 & iq & محيط فيزيكى & \\
\hline$r \wedge$ & rI & محيط صنعتى & \\
\hline 99199 & $\Delta \cdot$ & نظارت ناكافى & \multirow{4}{*}{ سطح ץ (بررسى يا نظارت نايمن) } \\
\hline YF & 11 & عمليات نامناسب برنامهريزىشده & \\
\hline TY/QG & IV & نقص در شناخت صحيح مشكل & \\
\hline it & 9 & تخلف يا تخطى بازرس كار & \\
\hline r. & $r \cdot$ & مديريت منابع & \multirow{3}{*}{ سطح † (تأثيرات سازمانى) } \\
\hline r & $r$ & 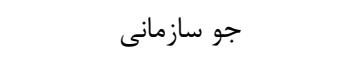 & \\
\hline r\&/99 & $r \cdot$ & فرايند سازمانى & \\
\hline
\end{tabular}


جدول r: نمونهاى از آناليز جند حادثه

\begin{tabular}{|c|c|c|c|c|}
\hline \multicolumn{3}{|c|}{ حادثه } & \multirow[b]{2}{*}{ نوع خطا } & \multirow[b]{2}{*}{$\begin{array}{r}\text { سطوح } \\
\text { HFACS }\end{array}$} \\
\hline سوختكى صورت & حست درثه قطع حين & حادثه فوت دو جورثه تغيير مسير & & \\
\hline $\begin{array}{l}\sqrt{ } \\
\sqrt{ }\end{array}$ & $\begin{array}{l}\sqrt{ } \\
\sqrt{ }\end{array}$ & $\begin{array}{l}\sqrt{ } \\
\sqrt{ } \\
\sqrt{ }\end{array}$ & 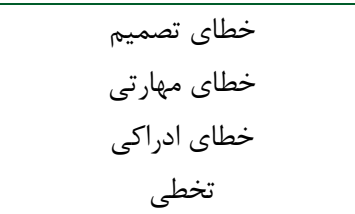 & سطح 1 \\
\hline$\sqrt{ }$ & $\begin{array}{l}\sqrt{ } \\
\sqrt{ }\end{array}$ & $\sqrt{ }$ & 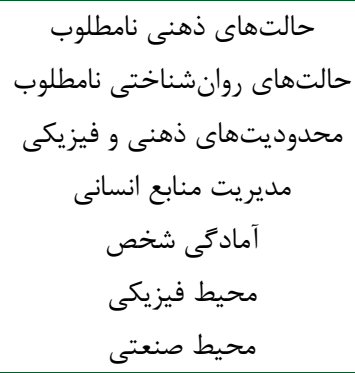 & سطح r \\
\hline $\begin{array}{l}\sqrt{ } \\
\sqrt{ }\end{array}$ & $\sqrt{ }$ & $\begin{array}{l}\sqrt{ } \\
\sqrt{ }\end{array}$ & نقص نمليات نامناسب برنامهريزىشده شناره & سطح r \\
\hline & $\begin{array}{l}\sqrt{ } \\
\sqrt{ }\end{array}$ & & مديريت منابع انسانى & سطح f \\
\hline
\end{tabular}

هايينتر جهار جوب HFACS بين سـطح f (تأثيرات سازمانى)

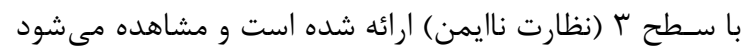

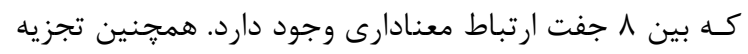

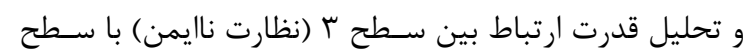

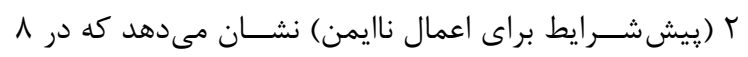

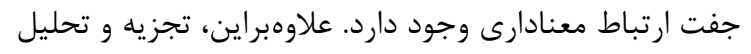

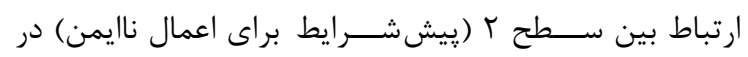

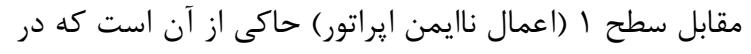
بين جفت زيركروهها ارتباط معنادارى وجود دارد.
از فاكتورهاى مؤثر در هر حادثه وجود دارد.

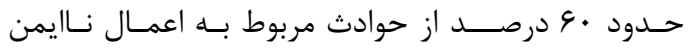
ايراتورها و ييششرايط براى اعمال نايمن مىباشند كه اصلاح و كاهش اين خطاها به برنامهريزى و توجه بيشـتر به إيراتورها نياز دارد. در جدول ץ بررسـى ارتباط معنادار بين دسـته داى سطح

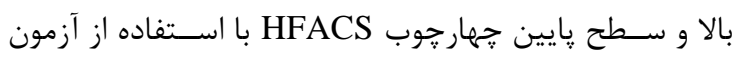
كاى دو نشان داده شده است. همان طور كه مشاهده مى شورد،

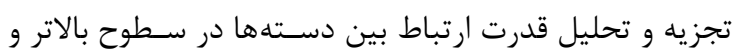

جدول بأ: بررسى ارتباط معنادارى بين دسته هاى سطح بالا و سطح پايين جهار جوب HFACS با استفاده از آزمون كاى دو

\begin{tabular}{|c|c|c|}
\hline 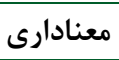 & 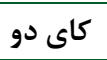 & تأثير سازمانى در مقابل نظارت ناايمن \\
\hline$<\cdot / \cdot \cdot 1$ & IV/Tr & فرايند سازمانى با تخطى بازرس كار \\
\hline$<\cdot / \cdot \cdot 1$ & $11 / \Delta \mu$ & فرايند سازمانى با نقص در شناخت صحيح مشكل \\
\hline$<\cdot / \cdot 1$ & $11 / r \wedge$ & فرايند سازمانى با عمليات نامناسب برنامهريزىشده \\
\hline$<\cdot / \cdot \cdot 1$ & TN/QT & فرايند سازمانى با نظارت ناكافى \\
\hline$<\cdot / \cdot 1$ & $19 / 7 V$ & جو سازمانى با تخطى بازرس كار \\
\hline$<\cdot / \cdot \cdot 1$ & tV/qK & جو سازمانى با نقص در شناخت صحيح مشكل \\
\hline$\cdot / \cdot r \Delta$ & $\Delta / \cdot r$ & جو سازمانى با نظارت ناكافى \\
\hline$\cdot / \cdot \Delta$ & V/AV & مديريت منابع با نظارت ناكافى \\
\hline \multicolumn{3}{|c|}{ نظارت نايمن در مقابل پييششرايط براى اعمال نايمن } \\
\hline $.1 \cdot 9$ & $r / \Delta \Lambda$ & نقص در شناخت صحيح مشكل با آمادگى شخص \\
\hline
\end{tabular}




\begin{tabular}{|c|c|c|}
\hline & & ادامه جدول ا. \\
\hline$\cdot / \cdot r$ & $\boldsymbol{f} / \Lambda$ & نقص در شناخت صحيح مشكل با حالت ذهنى نامطلوب \\
\hline$<\cdot / \cdot \cdot 1$ & $1 \cdot 198$ & عمليات نامناسب برنامهريزىشده با مديريت منابع انسانى \\
\hline$\cdot \mid \cdot \psi_{1}$ & F/Ts & عمليات نامناسب برنامهريزىشده با حالت ذهنى نامطلوب \\
\hline.$/ 1 \mathrm{VI}$ & T/9V9 & نظارت ناكافى با محيط صنعتى \\
\hline$\cdot / \cdot r$ & $r / 90$ & نظارت ناكافى با محيط فيزيكى \\
\hline$<\cdot / \cdot \bullet$ & $14 / V q$ & نظارت ناكافى با آمادگى شخص \\
\hline$<\cdot / \cdot 1$ & mI/AT & نظارت ناكافى با مديريت منابع انسانى \\
\hline$\cdot / \cdot r$ & $V / \Delta 9$ & نظارت ناكافى با محدوديتهاى ذهنى يا فيزيكى \\
\hline \multirow[t]{2}{*}{$<\cdot / \cdot \cdot 1$} & $19 / \mathrm{r}$ & نظارت ناكافى با حالت ذهنى نامطلوب \\
\hline & & ييشرايط براى اعمال ناايمن در مقابل اعمال نايمن \\
\hline$\cdot / \cdot 1$ & $9 / 9 \pi$ & محيط صنعتى با خطاهاى ادراكى \\
\hline$\cdot / \cdot v$ & $V / T \Delta$ & محيط صنعتى با خطاهاى بر پايه مهارت \\
\hline$\cdot / \cdot r$ & $\varphi / \Delta \varphi$ & محيط صنعتى با خطاهاى تصميم \\
\hline$<\cdot / \cdot \cdot 1$ & $11 / 9 \wedge$ & آمادگى شخص با خطاهاى بر پايه مهارت \\
\hline$<\cdot / \cdot \cdot 1$ & $\wedge / 9 \Lambda$ & آمادَّى شخص با خطاهاى تصميمم \\
\hline$<\cdot / \cdot \cdot 1$ & $1 \cdot / \mathrm{Ar}$ & مديريت منابع انسانى با تخطى \\
\hline$<\cdot / \cdot \cdot 1$ & r/94 & مديريت منابع انسانى با خطاهاى ادراكى \\
\hline$<\cdot / \cdot \cdot 1$ & rו/rی & مديرت منابع انسانى با خطاهاى بر پايه مهارت \\
\hline$<\cdot / \cdot \cdot 1$ & $r q / 4 \Lambda$ & مديريت منابع انسانى با خطاهاى تصميم \\
\hline$<\cdot / \cdot \cdot 1$ & $19 / 70$ & محدوديتهاى ذهنى يا فيزيكى با خطاهاى ادراكى \\
\hline$<\cdot / \cdot \cdot 1$ & r & محدوديتهاى ذهنى يا فيزيكى با خطاهاى بر پايه مهارت \\
\hline$<\cdot / \cdot \cdot 1$ & $r \cdot 10 \cdot$ & محدوديتهاى ذهنى يا فيزيكى با خطاهاى تصميمكيرى \\
\hline$<\cdot / \cdot \cdot 1$ & $1 \cdot 19 Y \wedge$ & 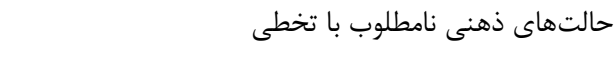 \\
\hline$<\cdot / \cdot \cdot 1$ & $r 9 / 9 V$ & حالتهاى ذهنى نامطلوب با خطاهاى ادراكى \\
\hline$<\cdot / \cdot \cdot 1$ & TN/DTT & حالتهاى ذهنى نامطلوب با خطاهاى بر پِايه مهارت \\
\hline$<\cdot / \cdot \cdot 1$ & $r q / r \Delta q$ & حالتهاى ذهنى نامطلوب با خطاهاى تصميم \\
\hline
\end{tabular}

يافتههاى اين يُزوهش نشان داد كه خطاهاى انسانى در

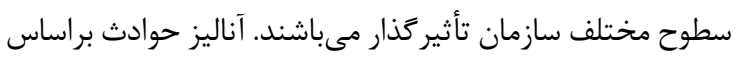

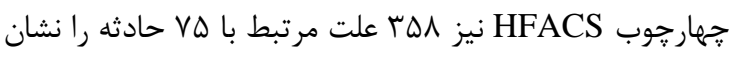

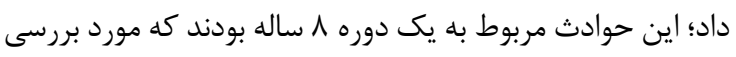

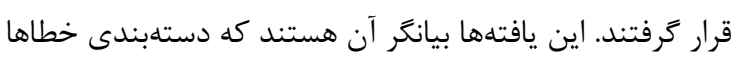

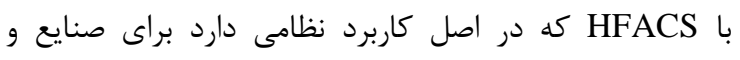

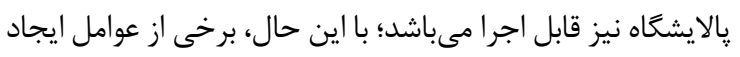

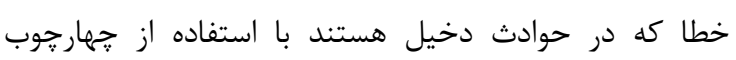

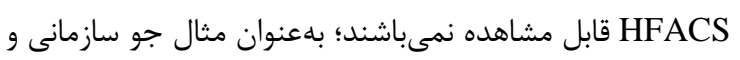

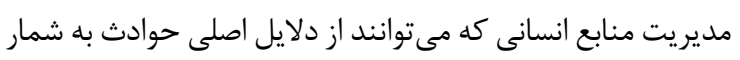

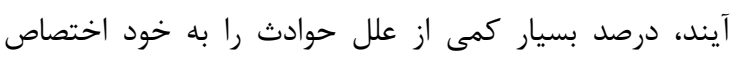

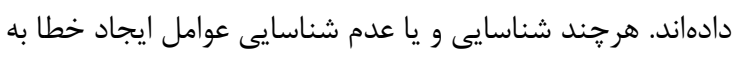

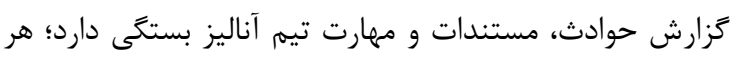

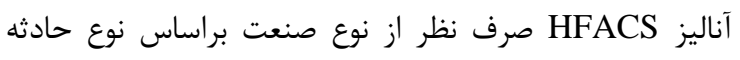

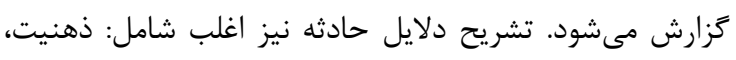

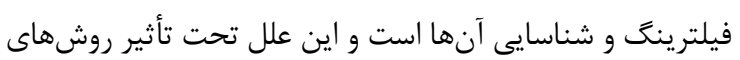

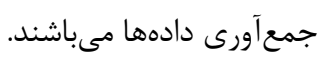

در اين مطالعه از جهارجوب HFACS تحليلى براى شناسايى خطاهاى فعال و ينهان انسان در حوادث پالايشخاه استفاده شد.

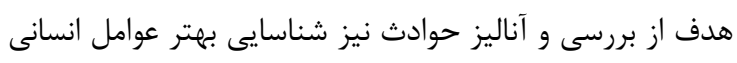

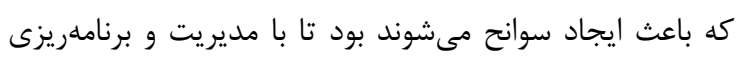

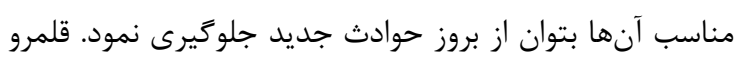

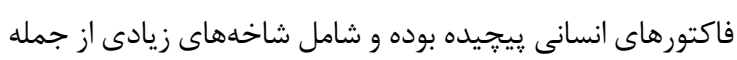

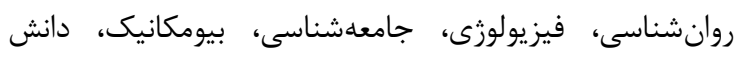

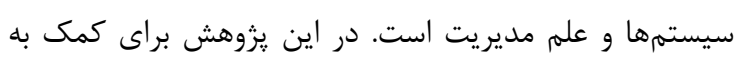

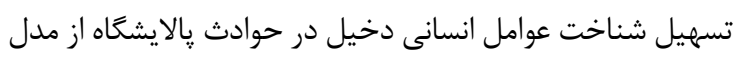
سيستم طبقهبندى و آناليز عوامل انسانى (HFACS) استفادي دخان

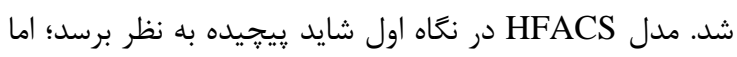

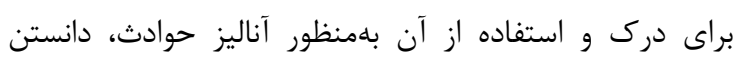

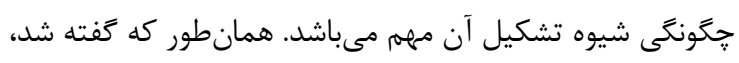

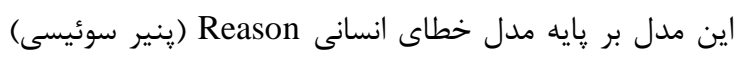

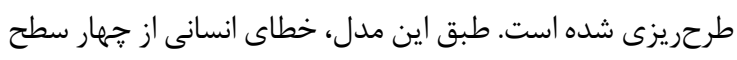

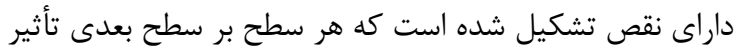

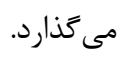


خود اختصاص داده است. در اين سطح، زيركروه "مديريت

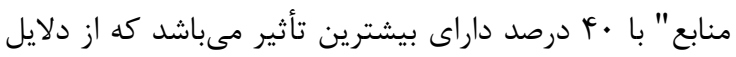

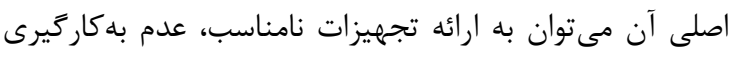

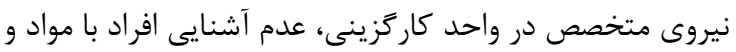

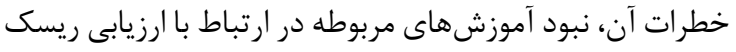

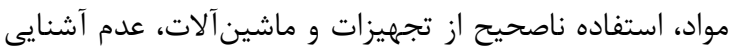

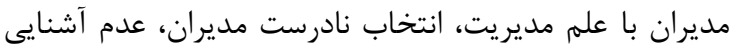

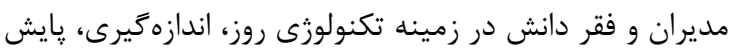

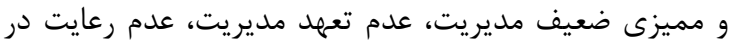

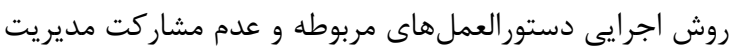

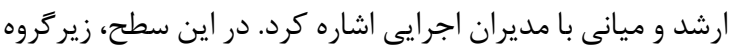

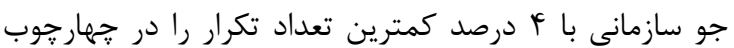
HFACS

يزوهشكران زيادى به بررسى و آناليز علل بروز حوادث

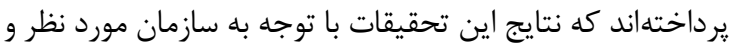

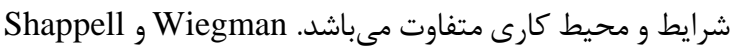

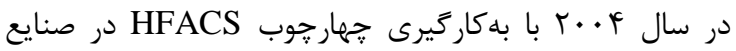

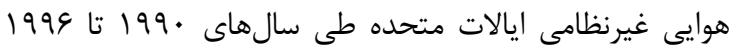

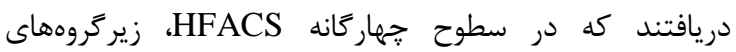

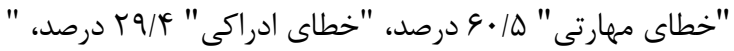

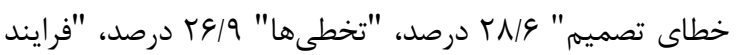

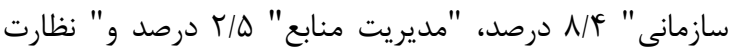

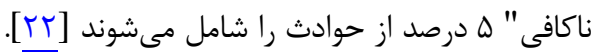
Li-Yang Ting

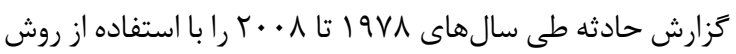

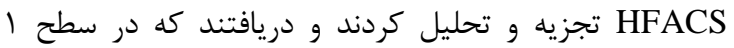

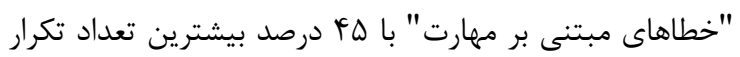

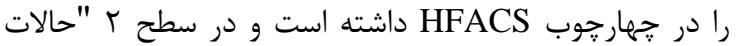

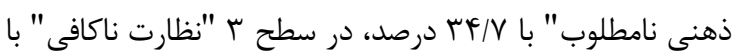

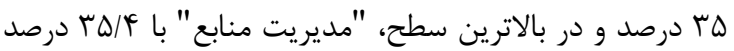

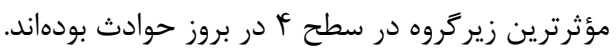

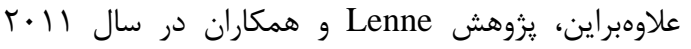
بهمنظور درك بهتر از عوامل سيستماتيك دخيل در حوادث داث سال
همانطور كه آناليز حوادث با استفاده از جهارجوب HFACS

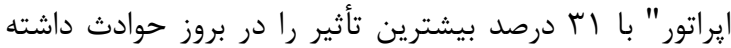

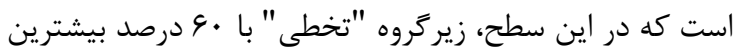

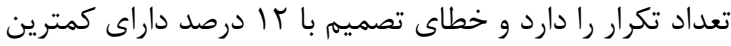

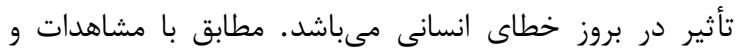

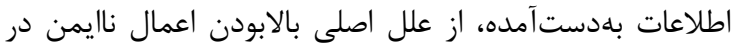

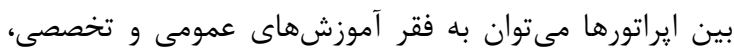

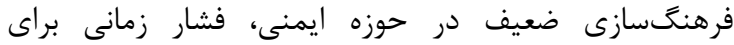
انجام كار، شتابزدىى، عدم استفاده از

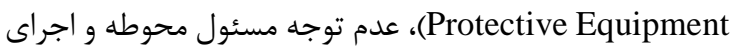
كار، اغماض در تجربه كارى، بىتجربكى و عدم بركزارى جارى جلسات

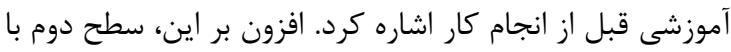

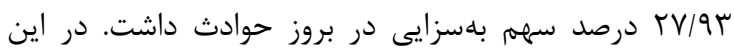

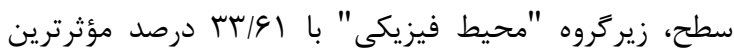
فاكتور در بروز خطاى انسانى است كه شامل دامل مسائلى مانند:

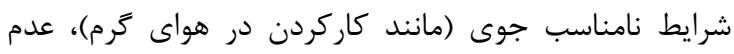

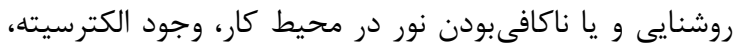

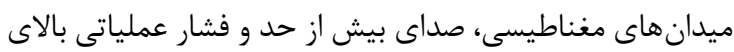

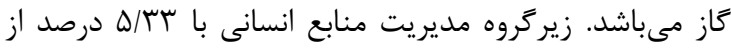

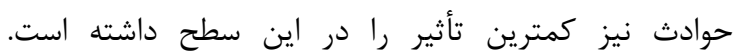

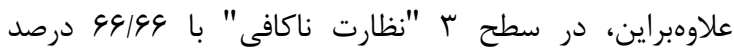

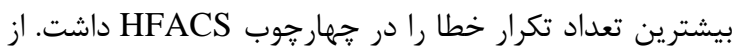

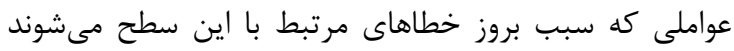

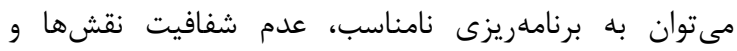

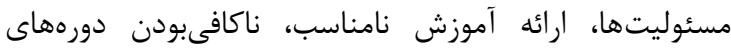

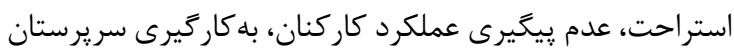

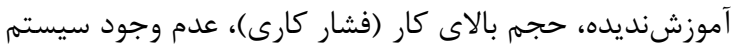

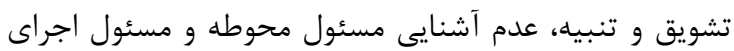
كار بر ماهيت كار و محدوديتهاى زمانى دانى در انجام كار اشاره كرد.

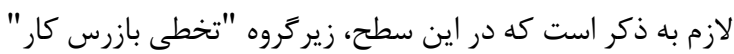

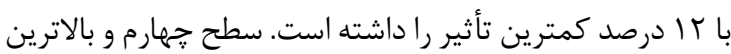

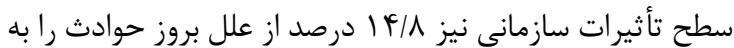

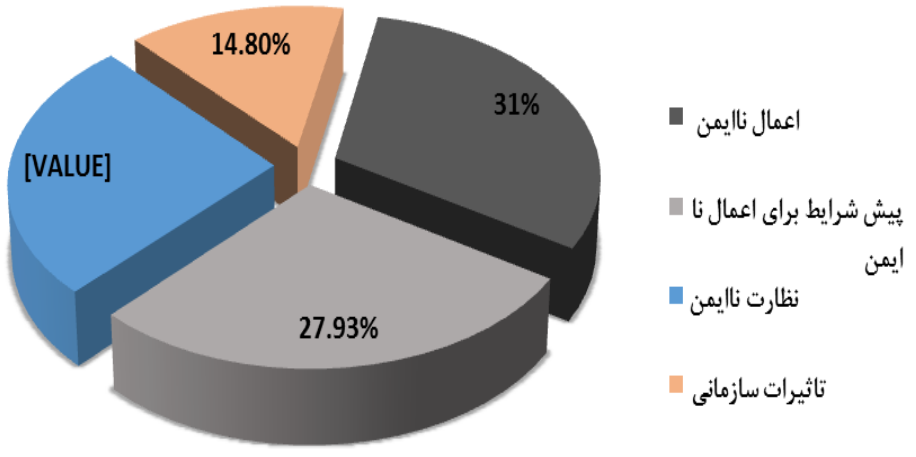

نمودار ا: سطوح توزيع خطاى انسانى 
مى گردد. جهار جوب HFACS داراى هر دو يايه نظرى و عملى براى توصيف اجزاى متعدد بررسى حوادث و برنامه يِيشَيرى از

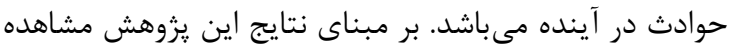

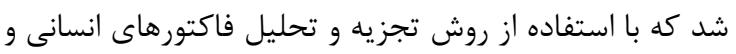
طبقهبندى سيستم (HFACS) مى توان خطاهاى انسانى مسبب حوادث در صنايع فرايندى را شناسايى نمود، تحليل كرد و آنها

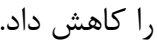

\section{نتيجه كيرى}

از آنجايى كه صنايع گَاز يكى از مهرمترين قطبهاى اقتصادى و درآمدى كشور محسوب مىشود و شاهد حوادث و قربانيان زيادى در اين قطب صنعتى هستيمى و بنّا بـ بر اهميت

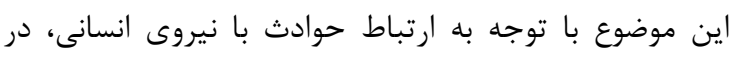

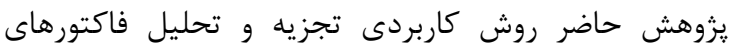

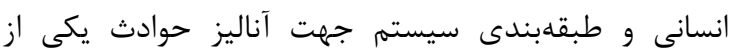

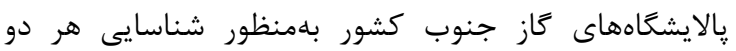

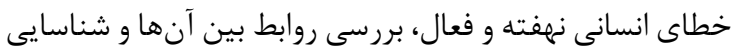

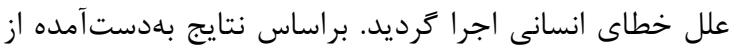

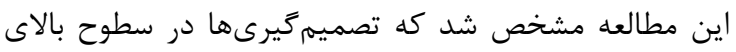

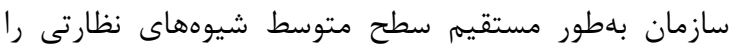

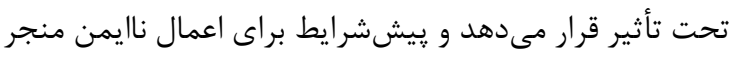

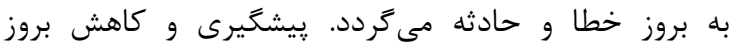

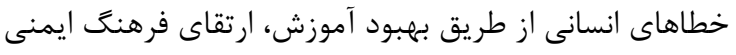

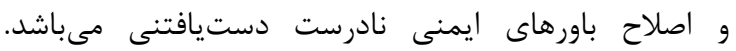

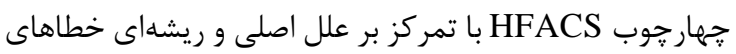

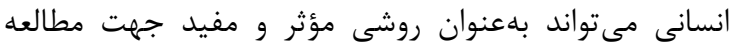

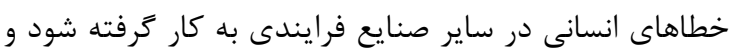

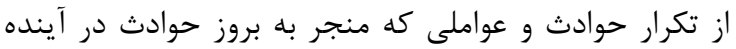

$$
\text { مىشوند، جلو ميرى نمايد. }
$$

\section{تشكر و قلروفاذى}

اين مقاله بركرفته از بخش عملى درس ايمنى مىباشد كه

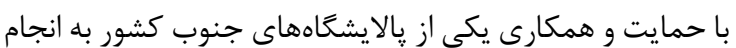

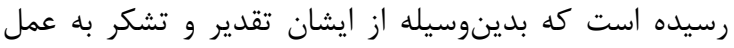
مى آيد.

\section{REFERENCES}

1. Jeoff S, Tim H, Jim J. Understanding human error in mine safety. Farnham, UK: Ashgate Publishing Limited; 2009.

2. General DS, Zctu MG, Negotiators TU. International labour office. Geneva: Pointers for a Global Safety Culture at Work ILO; 2003.

3. Kletz TA. An engineer's view of human error. Rugby: Institution of Chemical Engineers; 2001.

4. Daramola AY. An investigation of air accidents in Nigeria using the Human Factors Analysis and Classification System (HFACS) framework. J Air Transport Manag. 2014;35:3950. DOI: 10.1016/j.jairtraman.2013.11.004

5. Feyer AM, Williamson AM, Cairns DR. The involvement of human behaviour in occupational accidents: errors in context.
معدنى انجام شد و نقص نظارتى و سازمانى و عملكرد غيراستاندارد ايراتور را ي يشبينى نمود. بدينمنظور، سوب حادثه

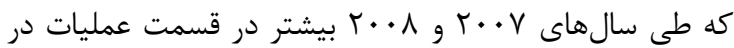
معدن استراليا رخ داده بودند، با استفاده از جهار تجوب HFACS تجزيه و تحليل شدند. در اين يزوهش گزارش گرديد كه در سطح

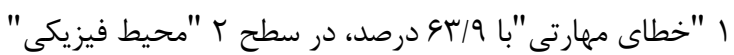
با 9/ه/ درصد، در سطح ب "عمليات نامناسب برنامهريزىشده"

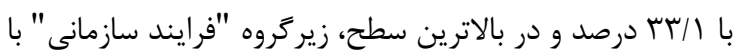
HFACS

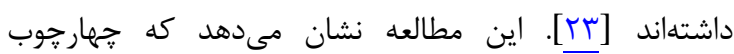

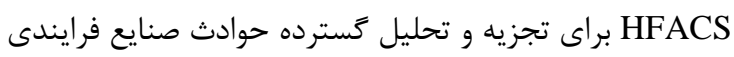
مناسب مىباشد و با بررسى آمارى ارتباط بين سطوح بالاى سازمان و سطوح يايين سازمان براساس شواهد تجربى مىتوان به درك درستى از اينكه جُگهونه اقدامات و تصميمات در سطوح بالاتر سازمان در سراسر يالايشگاه منجر به خطاهاى عملياتى و حوادث مى گر دند، دست يافت.

در مجموع، هدف از يزوهش حاضر توسعه يك روش تحليلى

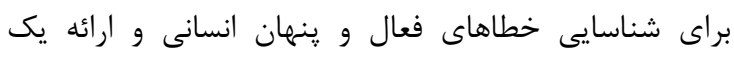
استراترى براى كاهش خطاى انسانى بود. در اين مطالعه براى شناسايى علل حوادث از متخصصان و كارشناسان و همجنين از مدلهاى HFACS و RCA استفاده ₹رديد. ابزارهايى نظير مى توانند درك عمومى از خطاى انسانى و ساز و كارهايى كه سبب بروز حوادث مىشوند را پيش روى ما قرار دهند. نتايج اين يزوهش نشان داد كه خطاها علل متفاوتى از جمله فردى، وابسته به فعاليت (وظيفه)، موقعيتى و سازمانى دارند كه براى حذف يا كاهش اين خطاها نياز به برنامهريزى و

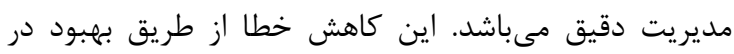
آموزش، ارتقاى فرهنَ ايمنى و اصلاح باورهاى ايمنى نادرست مانند اجتنابنايذيربودن وقوع حوادث، بهبود در سامانههاى بهني مديريتى و تجهيزات، افزايش دانش افراد و غيره دستيافتنى است. شايان ذكر مىباشد كه اين زيثوهش از خطاهاى فعال و نهفته مدل Reason در سازمان حمايت مى كند. تصميم گيرىها در سطوح بالاى سازمان بهطور مستقيم سطح متوسطى از شيوههاى نظارتى را تحت تأثير قرار مى بدهند و ييششرايط براى اعمال نايمن منجر به بروز خطا و حوادث

Safety Sci. 1997;25(1):55-65. DOI: 10.1016/S09257535(97)00008-8

6. Ghalenoei M, Asilian H, Mortazavi S, Varmazyar S. Human erroranalysis among petrochemical plant control room operators with human errorassessment and reduction technique. Iran Occupat Health. 2009;6(2):38-50. [Persian]

7. Stanton NA, Salmon P, Gibbon A, Jenkins D, Walker GH. Human factors methods and sports science: a practical guide. Florida: CRC Press; 2009

8. Diehl A. The effectiveness of training programs for preventing aircrew'error'. $6^{\text {th }}$ ed. Columbus, $\mathrm{OH}$ : International Symposium on Aviation Psychology; 1991.

9. Jensen RS. The boundaries of aviation psychology, human 
factors, aeronautical decision making, situation awareness, and crew resource management. Int J Aviation Psychol. 1997;7(4):259-67. DOI: 10.1207/s15327108ijap0704_1

10. Dekker SW. The disembodiment of data in the analysis of human factors accidents. Hum Factors Aerospace Saf. 2001;1(1):39-57.

11. Feggetter A. The development of an intelligent human factors data base as an aid for the investigation of aircraft accidents. $6^{\text {th }}$ ed. Columbus: International Symposium on Aviation Psychology; 1991.

12. Reason J. Human error. Cambridge: Cambridge University Press; 1990.

13. Dekker SW. Reconstructing human contributions to accidents: the new view on error and performance. $J$ Safety Res. 2002;33(3):371-85. PMID: 12404999

14. Boquet A, Detwiler C, Shappell S. A human factors analysis of US emergency medical transport accidents. Air Med J. 2004;23(5):34.

15. Shappell SA, Wiegmann DA. Applying reason: the human factors analysis and classification system (HFACS). Florida: Human Factors and Aerospace Safety; 2001.

16. Reinach S, Viale A. Application of a human error framework to conduct train accident/incident investigations. Accid Anal Prev. 2006;38(2):396-406. PMID: 16310153 DOI: 10.1016/j.aap.2005.10.013

17. Milligan FJ. Establishing a culture for patient safety-The role of education. Nurse Educ Today. 2007;27(2):95-102. PMID:
16713030 DOI: 10.1016/j.nedt.2006.03.003

18. ElBardissi AW, Wiegmann DA, Dearani JA, Daly RC, Sundt TM 3rd. Application of the human factors analysis and classification system methodology to the cardiovascular surgery operating room. Ann Thorac Surg. 2007;83(4):14129. PMID: 17383348 DOI: $10.1016 /$ j.athoracsur.2006.11.002

19. Ting FA, Dai SB. The identification of human errors leading to accidents for improving aviation safety. 14th International IEEE Conference on Intelligent Transportation Systems (ITSC), Washington, DC, USA; 2011. DOI: 10.1109/ ITSC.2011.6082793

20. Shirali G, Karami E, Goodarzi Z. Human errors identification using the human factors analysis and classification system technique (HFACS). Health Safety Work. 2013;3(3):45-54. [Persian]

21. Rooney JJ, Heuvel LN. Root cause analysis for beginners. Qual Progress. 2004;37(7):45-53.

22. Shappell SA, Wiegmann DA. HFACS analysis of military and civilian aviation accidents: A North American comparison. Proceedings of the Annual Meeting of the International Society of Air Safety Investigators, Canada; 2004.

23. Lenné MG, Salmon PM, Liu CC, Trotter M. A systems approach to accident causation in mining: An application of the HFACS method. Accid Anal Prev. 2012;48:111-7. PMID: 22664674 DOI: 10.1016/j.aap.2011.05.026 